\title{
ACCELERATING PUBERTY IN RAHMANI EWE LAMBS BORN IN AUTUMN AND WINTER BY GnRH INJECTION
}

\author{
Anas A. Salem ${ }^{1}$, S. Fahmy ${ }^{2}$ and A. Ali $^{3}$
}

1- Department of Animal Production, Faculty of Agriculture, University of Assiut, Assiut, Egypt, 2- Department of Animal Production, Faculty of Agriculture, University of Al-Azhar, Assiut, Egypt, 3-Department of Theriogenology, Faculty of Veterinary Medicine, University of Assiut, Assiut, Egypt

\section{SUMMARY}

The experiment examined the effect of body weight, season of birth and GnRH injection i.v. (5 $\mu \mathrm{g} / \mathrm{kg}$ body weight/animal 2-h intervals for 24 hours) on age at puberty and $P_{4}$ concentration in 10 Rhamni ewe lambs six months of age with mean body weight $19.88 \pm 0.78 \mathrm{~kg}$. This study started on June 20, 2001 and continued until the expected time of puberty in the Farm of Animal Production Department, Faculty of Agriculture, Al-Azhar University, Assiut. The ewe lambs were divided at random into two equal groups. The first group included three lambs born in autumn and two ewe lambs born in winter and this group was considered as control (Ctrl.). The second group also involved three ewe lambs born in autumn and two ewe lambs born in winter and this group was treated by GnRH i.v. injection and considered as treated ewe lambs (Tr.). After GnRH injection, two fertile rams were allowed to remain with each group for half an hour/day for estrus detection. All ewe lambs were fed the same ration with $11 \%$ crude protein and $12 \%$ ash. Each animal was given $750 \mathrm{~g}$ dry matter/daily of the ration which consisted of yellow corn, wheat straw, wheat bran and decorticated cotton seed meal. Green fodder, water and mineral blocks were freely available throughout the experiment. Blood samples were collected from the ewe lambs starting from June 20, 2002 until the expected time of puberty. Blood $(5 \mathrm{ml})$ was drawn from the jugular vein twice a week. Blood serum was separated and stored at $-20{ }^{\circ} \mathrm{C}$ until assayed for $\mathrm{P}_{4} \cdot$ When the $\mathrm{P}_{4}$ concentration reached the peak for the first time over $1.0 \mathrm{ng} / \mathrm{ml}$ blood serum, this was taken as the occurrence of puberty.

Results indicated that the difference between body weights of ewe lambs treated with GnRH and the Ctrl. lacked significance. The overall mean of Rahmani body weight at puberty represented 38-42\% of the adult body weight. There was no significant difference between the two groups in age at puberty. .Most treated lambs displayed higher $P_{4}$ concentrations than control lambs. Season of birth had also a highly significant effect $(p<0.01)$ on $P_{4}$ concentration. The first peak of serum $P_{4}$ (over $1.0 \mathrm{ng} / \mathrm{ml}$ ) concentrations occurred 99 days after the beginning of GnRH treatment, while the second peak of serum $P_{4}$ (over $1.0 \mathrm{ng} / \mathrm{ml}$ ) concentration occurred 90 days after the first peak of $P_{4}$. Treated lambs born in winter achieved the first peak of $P_{4}$ concentration much earlier than control lambs born in autumn. So, GnRH was more effective in lambs born in winter than those born in autumn in accelerating the time of puberty in Rahmani ewe lambs.

Kew words : Puberty, Rahmani lambs, body weight, season of birth, GnRH and $\mathrm{P}_{4}$.

Issued by The Egyptian Society of Animal Production 


\section{INTRODUCTION}

Puberty in the female sheep depends on body development, birth date, photoperiod length and management There is relatively little activity of the ovary prior to puberty. At the time of puberty, it begins the distinct functional rhythm known as the estrous cycle. There is evidence that month of birth will subsequently influence the age of puberty. The easiest image of puberty in the female sheep is the completion of the first follicular phase that successfully results in ovulation. Sheep breeds differ in occurrence of their initial reproductive cycle. For example, puberty in Rahmani sheep is between $12-17$ mo compared to European breeds such as Rmbouillet, 277 days, Finnsheep, 258 days, Finn-Dorset 260 days, Dorset, 234 days, Suffolk; 245 days (Quirke et al., 1985). Age at first estrus is affected by both genetic and environmental factors. Application of exogenous treatments either by infusion, ingestion or injection is successfully used now in farm animals, because of the beneficial effects either in increasing the reproductive rate or in advancing the breeding season. Moreover, it reduces the unproductive period in the ewe's lifetime which extends from weaning to the first estrus (Dickerson, 1970). However, accelerating puberty in Egyptian sheep has received little attention, so the main purpose of this study was the estimation of age at puberty and investigation of the acceleration of the rate to reach puberty in Rahmani ewe lambs.

\section{MATERIALS AND METHODS}

A total of 10 autumn and winter-born Rahmani ewe lambs six months of age (with mean body weight $19.88 \pm 0.78 \mathrm{~kg}$ ) were divided at random into two equal groups. The first group included three lambs born in autumn and two ewe lambs born in winter and this group was considered as control lambs (Ctrl.). The second group also involved three ewe lambs born in autumn and two ewe lambs born in winter and this group was treated by GnRH i.v. injection and considered as treated ewe lambs (Tr.). Birth dates and dates of puberty of all ewe lambs are presented in Table (1). Each group was housed in $20 \mathrm{~m}^{2}$ semi-open pen under the natural daylight length.

Table 1. Dates of birth and puberty ewes

\begin{tabular}{llll}
\hline $\begin{array}{c}\text { Animal } \\
\text { number }\end{array}$ & Group & \multicolumn{1}{c}{$\begin{array}{c}\text { Birth date of ewe } \\
\text { lamb }\end{array}$} & \multicolumn{1}{c}{ Date of puberty } \\
\hline 1 & Ctrl. & Sept. 26, 2001 & Nov. 10, 2002 \\
2 & Ctrl. & Dec. 1, 2001 & Sept. 30, 2002 \\
3 & Ctrl. & Nov. 27, 2001 & Oct. 13, 2002 \\
4 & Ctrl. & Jan. 15,2002 & Estrus was not detected by the ram \\
5 & Ctrl. & Oct. 24, 2001 & Died on Nov. 10, 2002 \\
1 & Tr. & Nov. 24, 2001 & Estrus was not detected by the ram \\
2 & Tr. & Jan. 3, 2002 & Sept. 30, 2002 \\
3 & Tr. & Oct. 26, 2001 & Nov. 17, 2002 \\
4 & Tr. & Sept. 1, 2001 & Oct. 19, 2002 \\
5 & Tr. & Jan. 21, 2002 & Nov. 17, 2002 \\
\hline
\end{tabular}

All nutritional and climatic conditions were considered random or free from bias. Management of the ewe lambs was conducted in accordance with recommended commercial practices in the Farm of Animal Production Department, Faculty of 
Agriculture, Al-Azhar University, Assiut. Lambs fed the same ration containing 11 $\%$ crude protein and $12 \%$ ash. Each animal was given $750 \mathrm{~g}$ dry matter/day (3\% dry matter of its body weight) of the ration which consisted of yellow corn, wheat straw, wheat bran and decorticated cotton seed meal. Green fodder, water and mineral blocks were freely available throughout the experiment. All ewe lambs were weighed in $\mathrm{kg}$ once a month for five months.

$\mathrm{GnRH}$ was injected intra venous at the rate of $5 \mu \mathrm{g} / \mathrm{kg}$ body weight/animal 2-h intervals for 24 hours by means of an indwelling jugular catheter to treated ewe lambs (Tr.) (Racabarren et al., 2000), while the Ctrl group did not receive any treatment. After GnRH injection, two fertile rams were allowed to remain with each group early in the morning at 8:00 a.m. for half an hour for estrus detection. The rams were rotated biweekly between the two groups to avoid the ram effect.

Blood samples were collected from all ewe lambs starting from June 20, 2002 until the expected time of puberty. Blood $(5 \mathrm{ml})$ was drawn from the jugular vein twice a week. Blood samples were kept overnight in the refrigerator at $4{ }^{\circ} \mathrm{C}$, then blood serum was separated and stored at $-20{ }^{\circ} \mathrm{C}$ until assayed for $\mathrm{P}_{4}$ so as to determine the time of puberty. It was considered that puberty occurred if the $\mathrm{P}_{4}$ concentration rose to the peak for the first time over $1.0 \mathrm{ng} / \mathrm{ml}$ blood serum (Suttie et al., 1991 and Al-Mauly et al., 1991).

\section{Progesterone $\left(\mathrm{P}_{4}\right)$ assay}

$\mathrm{P}_{4}$ was assayed by enzyme immunoassay (ELISA) described by DSL (2000).

Data were analyzed using analysis of variance with SPSS for MS Window Release 6.0. Body weight, age at puberty and $\mathrm{P}_{4}$ profile are dependent variables , while the main effects in the model are GnRH injection, the interval from start of GnRH injection to the expected time of puberty and season of birth. Significance was taken at $(\mathrm{p}<0.05$ and $\mathrm{p}<0.01)$.

\section{RESULTS AND DISCUSSION}

\section{Body weight:}

Estimates of mean body weight of all ewe lambs throughout the experiment are presented in Table (2). The difference between body weights of ewe lambs treated and the Ctrl. lacked significance.

Table 2. Overall mean of monthly body weight development throughout the course of study.

\begin{tabular}{llllll}
\hline Group & & \multicolumn{4}{c}{ Monthly body weight in kg } \\
\hline \multirow{3}{*}{ Ctrl. } & Jun. & July & Aug. & Sept. & Nov. \\
\cline { 2 - 6 } & $20.88 \pm 0.86$ & $20.88 \pm 1.07$ & $22.0 \pm 1.41$ & $24.75 \pm 2.08$ & $24.75 \pm 3.06$ \\
Tr. & $(\mathrm{n}=5)$ & $(\mathrm{n}=5)$ & $(\mathrm{n}=5)$ & $(\mathrm{n}=5)$ & $(\mathrm{n}=5)$ \\
& $18.88 \pm 0.69$ & $20.25 \pm 0.76$ & $20.75 \pm 0.76$ & $22.50 \pm 1.06$ & $25.75 \pm 1.55$ \\
& $(\mathrm{n}=5)$ & $(\mathrm{n}=5)$ & $(\mathrm{n}=5)$ & $(\mathrm{n}=5)$ & $(\mathrm{n}=4)$ \\
\hline
\end{tabular}

$\mathrm{n}=$ number of animals.

There is a gradual increase in the mean body weight in the interval from June to November (near the time of puberty). At the time of puberty, treated lambs had an advantage of $1.0 \mathrm{~kg}$ over those in the Ctrl. This increase may be due to the difference in birth weight or to the effect of GnRH dose. Yamasaki et al. (2001) indicated that GnRH increased the percentage of body fat and the trunk-leg fat ratio, but decreased 
lean mass deposit with no change in body weight. The reason why GnRH treatment induces body fat distribution is the complete suppression of ovarian steroids. Estrogen deficiency by GnRH may influence gluteofemoral adiposity with the pubertal onset of ovarian function (Rebuffe-Scribe et al., 1986). The present results indicated that the average body weight at puberty of treated and control ewe lambs represented 38.0-42.0\% of the adult body weight (on basis of adult body weight in Rahmani female is between 60.0 and $65.0 \mathrm{~kg}$ ). Results obtained by Hafez (1952) support these findings. He indicated that attainment of puberty is more closely related to body weight than to age, Romney ewes reached puberty when the body weight is $40 \%$ of the adult weight.

\section{Age and time at puberty}

Age at first estrus was relatively lower in the treated lambs (340.5 \pm 20.07 days) compared to those in the Ctrl. (341.5 \pm 34.19 days) (Table 3). There was no significant difference between the two groups in age at puberty, but season of birth had a significant effect $(\mathrm{p}<0.05)$ on age of puberty. Ewe lambs born in winter resulted in earlier puberty (287.3 \pm 13 .1.days) than those born in autumn (381.00 \pm 22.5 .days).

Table 3. Age at puberty (days) in Ctrl. and Tr. ewe lambs born in autumn and winter

\begin{tabular}{llll} 
& \multicolumn{3}{c}{ Age at puberty in days } \\
\cline { 2 - 4 } & Ctrl. & Tr. & $\begin{array}{l}\text { Overall } \\
\text { mean }\end{array}$ \\
\cline { 2 - 4 } $\begin{array}{l}\text { Season of birth } \\
\text { Overall }\end{array}$ & $\begin{array}{l}341 \pm 34.2 \\
(\mathrm{n}=3)\end{array}$ & $\begin{array}{l}340 \pm 20.1 \\
(\mathrm{n}=4)\end{array}$ & $\begin{array}{l}341 \pm 26.1 \\
(\mathrm{n}=7)\end{array}$ \\
Autumn & $362 \pm 38.1$ & $400 \pm 28.4$ & $381 \pm 22.5$ \\
& $(\mathrm{n}=2)$ & $(\mathrm{n}=2)$ & $(\mathrm{n}=4)$ \\
Winter* & $299 \pm$ & $282 \pm 16.0$ & $287 \pm 13.1$ \\
& $(\mathrm{n}=1)$ & $(\mathrm{n}=2)$ & $(\mathrm{n}=3)$ \\
\hline
\end{tabular}

$\mathrm{n}=$ number of animals in the experiment

Papachristoforou et al. (2000) indicated that the age and live weight at puberty in autumn-born Chios ewe lambs were higher $(\mathrm{P}<0.01)$ than in February-born ones, the respective values being 33 weeks and $51.1 \mathrm{~kg}$ versus 29.9 weeks and $42.0 \mathrm{~kg}$. Furthermore, in Damascus she-kids born in autumn or in February, onset of puberty was at the same time in the following autumn (Papchristoforou et al., 2000). Foster and Ryan (1979) reported that in lambs born in late winter and spring, puberty occurred in autumn between 25 and 35 weeks of age. Hafez and Scott (1962) indicated that ewe lambs differed in their ages at puberty between 6-16 months and this variation was attributed to climate and season of birth. The present results indicated that all the control and treated lambs born in winter, puberty occurred in the next autumn, whereas those born in autumn , puberty occurred in the next autumn (Table 1). These results are consonant with that reported by Geithovel et al. (1985) who indicated that pulsatile GnRH application can induce ovarian hyperstimulation. Pirl and Adams (1987) indicated also that Circhoral administration (250 ng/h i.v.) of GnRH was effective in inducing precocious puberty in ewe lambs. Foster et al., (1983) indicated that a deficit in GnRH production may delimit the prepubertal 
development in primates. Laws et al. (2003) observed that i.v. injection of GnRH restored the estrogen-induced secretion of LH in the pubertal development of female Wister rats. Therefore, exogenous administration of $\mathrm{GnRH}$ has a potential effect for induction of precocious puberty especially in ewe lambs born in winter.

\section{Progesterone profiles}

Results in Table (4) indicate that there are highly significant differences $(\mathrm{P}<0.01)$ among individuals within each group in $\mathrm{P}_{4}$ concentrations. Treated lambs displayed higher $\mathrm{P}_{4}$ concentrations than control lambs (Figure 1). During the interval from start of $\mathrm{GnRH}$ treatment to the expected time of puberty, $\mathrm{P}_{4}$ concentration was less than $1.0 \mathrm{ng} / \mathrm{ml}$ blood serum in all the lambs except one lamb of the treated group which showed $\mathrm{P}_{4}$ concentration over $1.0 \mathrm{ng} / \mathrm{ml}$ (Figure 1). The overall mean of $\mathrm{P}_{4}$ concentrations in control and treated lambs and in the ewe lambs born in autumn and winter are shown in Figure (2). Season of birth had also highly significant effect $(p<0.01)$ on $\mathrm{P}_{4}$ concentration (Table 5). This table reveals that there are two peaks of $\mathrm{P}_{4}$ concentration (over $1.0 \mathrm{ng} / \mathrm{ml}$ blood serum) that occurred in all the lambs. The first peak of $\mathrm{P}_{4}$ concentrations occurred 99 days after beginning of GnRH treatment (from June 20, 2002 to September 28, 2002), while the second peak of $\mathrm{P}_{4}$ concentration occurred 90 days after the first peak of $\mathrm{P}_{4}$ concentration (from September 28, 2002 to December 27, 2002) (Table 5). Furthermore, magnitudes of $\mathrm{P}_{4}$ peak concentration in treated lambs $(1.34 \pm 0.37 \mathrm{ng} / \mathrm{ml}$ and $1.77 \pm 0.57 . \mathrm{ng} / \mathrm{ml})$ were greater than control lambs $(1.09 \pm 0.20 \mathrm{ng} / \mathrm{ml}$ and $1.0 \pm 0.32 \mathrm{ng} / \mathrm{ml})$. This increase of $\mathrm{P}_{4}$ concentration can reflect its early effect on the ovarian activity and CL formation. These findings are similar to those reported by Suttie et al. (1991) who indicated that puberty was defined as the date when plasma of $\mathrm{P}_{4}$ concentration first exceeded 1.0 $\mathrm{ng} / \mathrm{ml}$. McNatty et al. (1998) indicated that pubertal development was defined in ewe lambs from behavioral estrus and from $\mathrm{P}_{4}$ concentration. Season of birth has a strong significant effect on $\mathrm{P}_{4}$ concentration, especially with ewe lambs treated with GnRH injection (Figure 3). Furthermore, treated lambs born in winter achieved earlier first peak of serum $\mathrm{P}_{4}$ concentration in August, 2002 than control lambs born in autumn which produced the first peak of $\mathrm{P}_{4}$ concentration in September, 2002 (Table 6). So, GnRH was more effective in lambs born in winter than those born in autumn. In this study, puberty was attained at a significantly earlier age in the treated ewe lambs born in winter compared to the control lambs born in autumn. $\mathrm{P}_{4}$ concentration may have a physiological role in the endocrine mechanism governing transitions from acyclic to cyclic states and that a transient increase in $\mathrm{P}_{4}$ concentration ensures LH surge to initiate an estrous cycle in anestrous ewe (Legan et al., 1985). McLeod et al., (1991) indicated that administration of $\mathrm{GnRH}$ given either intermittently i.v. (2.0 $\mu \mathrm{g}$ /injection at 2-h intervals) for 4 days or continuously s.c. infusion $(1.0 \mu \mathrm{g} / \mathrm{h})$ for 14 days induced ovulation in a proportion of seasonally anoestrous Pere David's deer. 
Table 4. Mean \pm SEM of blood serum $P_{4}$ concentration in individuals within each group of Ctrl. and Tr. ewe lambs

\begin{tabular}{lccc}
\hline \# Animal & $\begin{array}{c}\text { Group of } \\
\text { animals }\end{array}$ & $\begin{array}{c}\text { Number of } \\
\text { observations }\end{array}$ & $\begin{array}{c}\mathbf{P}_{\mathbf{4}} \text { concentration } \\
(\mathbf{n g} / \mathbf{m l} \text { blood serum }\end{array}$ \\
\hline 1 & $\mathrm{Ctrl}^{* *} \cdot$ & 26 & $0.78 \pm 0.13$ \\
2 & $\mathrm{Ctrl}^{* *}$ & 26 & $0.62 \pm 0.09$ \\
3 & $\mathrm{Ctrl}^{* *}$ & 17 & $0.84 \pm 0.25$ \\
4 & $\mathrm{Ctrl}^{* *}$ & 17 & $0.38 \pm 0.16$ \\
5 & $\mathrm{Ctrl}^{* *}$ & Not detected & \\
\hline Total & $\mathrm{Ctrl}^{* *}$ & $\mathbf{8 6}$ & $\mathbf{0 . 6 6} \pm \mathbf{0 . 8}$ \\
1 & $\mathrm{Tr}^{* *}$ & 24 & $0.57 \pm 0.11$ \\
2 & $\mathrm{Tr}^{* *}$ & 18 & $0.81 \pm 0.21$ \\
3 & $\mathrm{Tr}^{* *}$ & 23 & $0.65 \pm 0.11$ \\
4 & $\mathrm{Tr}^{* *}$ & 17 & $1.26 \pm 0.31$ \\
5 & $\mathrm{Tr} .{ }^{* *}$ & No detected &. \\
Total & $\mathrm{Tr}$. & $\mathbf{8 2}$ & $\mathbf{0 . 8 2} \pm \mathbf{0 . 0 9}$ \\
\hline
\end{tabular}

significance among individuals within each group was high $(\mathrm{p}<0.01)$

Table 5. Level of $P_{4}, \mathrm{ng} / \mathrm{ml}$ blood serum, in the interval from start of GnRH treatment (June, 2002) until the expected time of puberty (December, 2002) in Ctrl. and Tr. ewe lambs

\begin{tabular}{llllllll}
$\begin{array}{l}\text { Group of } \\
\text { animals }\end{array}$ & \multicolumn{7}{c}{ Month of blood collection } \\
\cline { 2 - 8 } Control & June & July & August & September & October & November & December \\
\cline { 2 - 8 } & $0.30 \pm 0.02$ & $0.40 \pm 0.07$ & $0.91 \pm 0.37$ & $1.09 \pm 0.20$ & $0.58 \pm 0.06$ & $0.86 \pm 0.24$ & $1.0 \pm 0.32$ \\
& $(\mathrm{n}=13)$ & $(\mathrm{n}=25)$ & $(\mathrm{n}=9)$ & $(\mathrm{n}=15)$ & $(\mathrm{n}=9)$ & $(\mathrm{n}=12)$ & $(\mathrm{n}=3)$ \\
Treatment & $0.61 \pm 0.21$ & $0.38 \pm 0.04$ & $0.86 \pm 0.25$ & $1.34 \pm 0.37$ & $0.81 \pm 0.31$ & $0.50 \pm 0.18$ & $1.77 \pm 0.57$ \\
& $(\mathrm{n}=14)$ & $(\mathrm{n}=22)$ & $(\mathrm{n}=11)$ & $(\mathrm{n}=16)$ & $(\mathrm{n}=7)$ & $(\mathrm{n}=8)$ & $(\mathrm{n}=4)$ \\
\hline
\end{tabular}

$\mathrm{n}=$ number of observations.

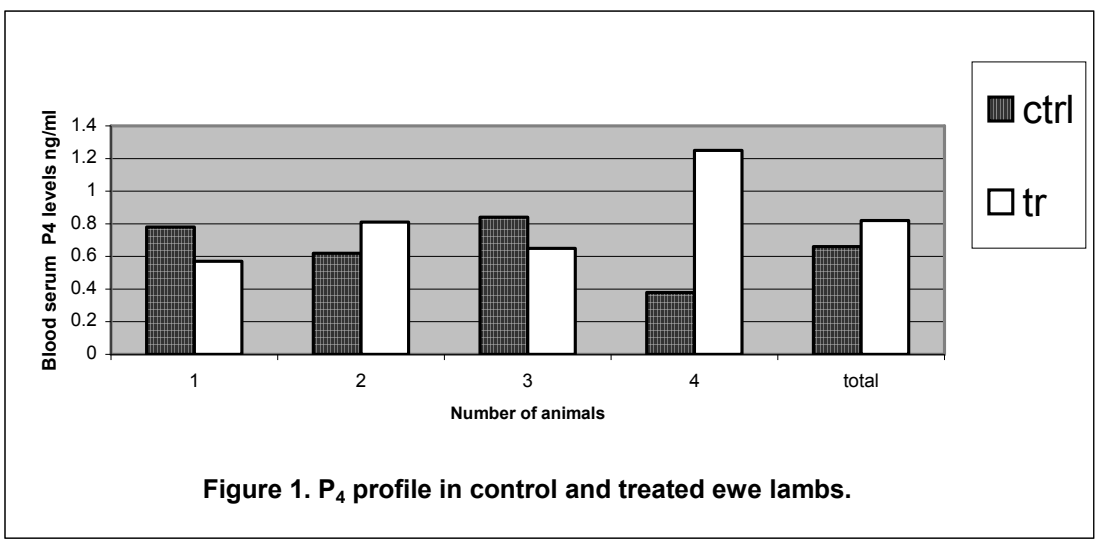




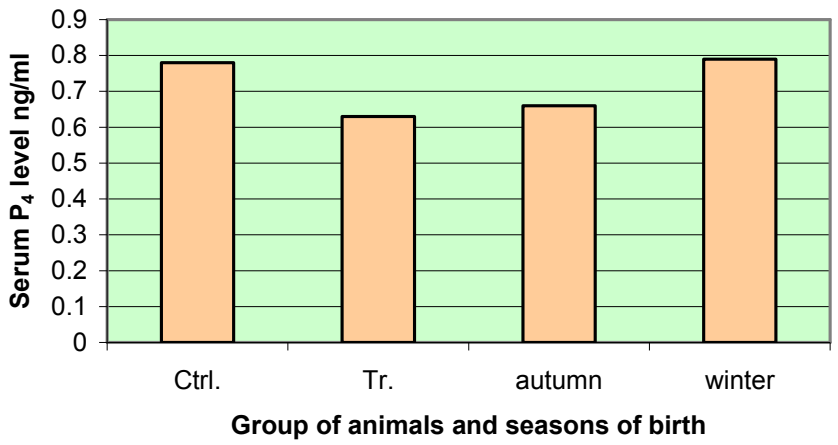

Figure 2. The overall mean of $P_{4}$ level in all lambs and ewe lambs born in autumn and winter.

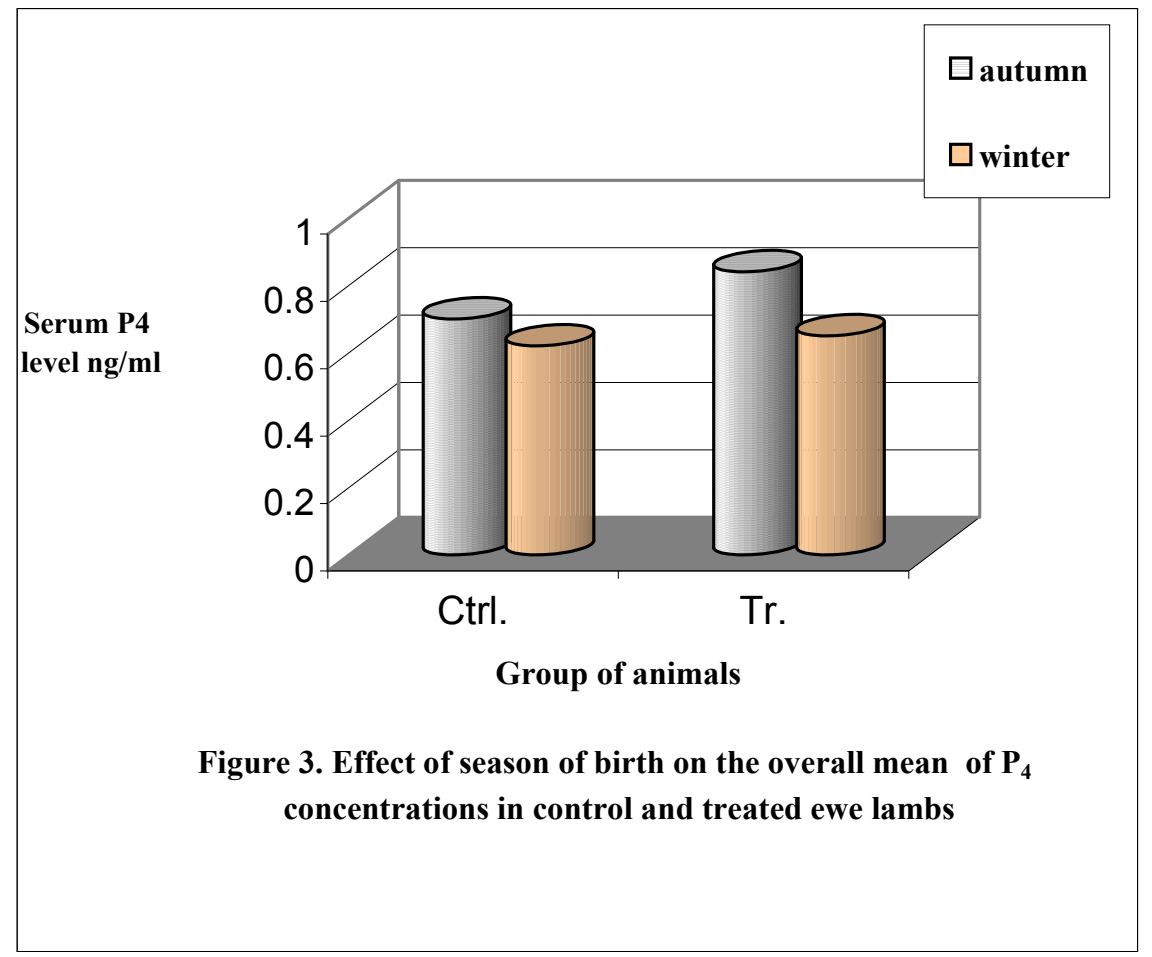


Table 6. Effect of season of birth on the average blood serum $\mathrm{P}_{4}$ concentration in the interval from start of GnRH treatment (June, 2002) until the expected time of puberty (December, 2002) in Ctrl. and Tr. ewe lambs

\begin{tabular}{|c|c|c|c|c|c|c|c|c|c|c|c|c|c|c|}
\hline $\begin{array}{l}\text { Season of } \\
\text { birth }\end{array}$ & & & & & & Mon & $s$ of blo & sera co & ection & & & & & \\
\hline \multirow[b]{3}{*}{ Autumn } & \multicolumn{2}{|c|}{ Jun. } & \multicolumn{2}{|c|}{ Jul. } & \multicolumn{2}{|c|}{ Aug. } & \multicolumn{2}{|c|}{ Sept. } & \multicolumn{2}{|c|}{ Oct. } & \multicolumn{2}{|c|}{ Nov. } & \multicolumn{2}{|c|}{ Dec. } \\
\hline & Ctrl. & Tr. & Ctrl.. & Tr. & Ctrl.. & Tr. & Ctr.l. & Tr. & Ctrl.. & Tr. & Ctrl.. & Tr. & Ctr.l. & Tr. \\
\hline & $\begin{array}{c}0.30 \\
(\mathrm{n}=7)\end{array}$ & $\begin{array}{c}0.68 \\
(n=10)\end{array}$ & $\begin{array}{c}0.52 \\
(\mathrm{n}=12)\end{array}$ & $\begin{array}{c}0.38 \\
(n=15)\end{array}$ & $\begin{array}{c}0.93 \\
(\mathrm{n}=4)\end{array}$ & $\begin{array}{c}0.74 \\
(\mathrm{n}=7)\end{array}$ & $\begin{array}{c}1.19 \\
(\mathrm{n}=8)\end{array}$ & $\begin{array}{c}1.51 \\
(\mathrm{n}=12)\end{array}$ & $\begin{array}{c}0.38 \\
(\mathrm{n}=5)\end{array}$ & $\begin{array}{c}0.88 \\
(\mathrm{n}=6)\end{array}$ & $\begin{array}{c}0.90 \\
(\mathrm{n}=6)\end{array}$ & $\begin{array}{c}0.50 \\
(\mathrm{n}=6)\end{array}$ & $\begin{array}{c}1.50 \\
(\mathrm{n}=1)\end{array}$ & $\begin{array}{l}1 . .85 \\
(\mathrm{n}=3)\end{array}$ \\
\hline Winter & $\begin{array}{c}0.30 \\
(\mathrm{n}=6)\end{array}$ & $\begin{array}{c}0.45 \\
(\mathrm{n}=4)\end{array}$ & $\begin{array}{c}0.30 \\
(\mathrm{n}=13)\end{array}$ & $\begin{array}{c}0.36 \\
(\mathrm{n}=7)\end{array}$ & $\begin{array}{c}0.90 \\
(\mathrm{n}=5)\end{array}$ & $\begin{array}{c}1.08 \\
(\mathrm{n}=4)\end{array}$ & $\begin{array}{c}0.97 \\
(\mathrm{n}=7)\end{array}$ & $\begin{array}{c}0.85 \\
(\mathrm{n}=4)\end{array}$ & $\begin{array}{c}0.83 \\
(\mathrm{n}=4)\end{array}$ & $\begin{array}{c}0.40 \\
(\mathrm{n}=1)\end{array}$ & $\begin{array}{c}0.83 \\
(\mathrm{n}=6)\end{array}$ & $\begin{array}{c}0.50 \\
(\mathrm{n}=2)\end{array}$ & $\begin{array}{c}0.75 \\
(\mathrm{n}=1)\end{array}$ & $\begin{array}{c}1.50 \\
(\mathrm{n}=2)\end{array}$ \\
\hline
\end{tabular}

$\mathrm{n}=$ number of observations 
It could be concluded of the study that there was no significant difference between body weights of ewe lambs treated with GnRH and the Ctrl.. Ewe lambs born in winter in both groups exhibited earlier puberty than those born in autumn . Furthermore, most treated lambs displayed higher $\mathrm{P}_{4}$ concentrations than control lambs. Treated lambs born in winter achieved the first peak of $\mathrm{P}_{4}$ concentration much earlier than control lambs born in autumn. So, GnRH was more effective in lambs born in winter than those born in autumn in the acceleration of puberty in Rahmani ewe lambs.

\section{REFERENCES}

Al-Mauly, N.Z.N., M.J. Bryant and F.J. Cunningham 1991. Effect of introduction of rams on the pulsatile release of luteinizing hormone and the onset of reproductive activity in ewe lambs $>$ Anim. Prod. , 53:209-214.

Dickerson, G.E. 1970. Efficiency of animal productivity. J. Anim. Sci., 30:849-852.

DSL, 2000. Active progesterone EIA, DSL-10-3900

Foster, D.L. and K.D. Ryan, 1979. Endocrine mechanisms governing transition into adulthood: a mark decrease in inhibitory feedback action of estradiol on tonic secretion of lutinizing hormone in the lamb during puberty. Endocrinology, 105:896

Foster, D.L., J.J. Rapisarda, K.S. Bergman, J.A. Lemons, R.B. Jaffe, R.A. Steiner and R.C. Wolf 1983. In "Neuroendocrine aspects of reproduction" (Norman, R.L., ed.), p. 149, academic Press, New York.

Geisthovel, F., F. Peter and M. Breckwoldt 1985. Hyperstimulation due to long-term pulsatile intravenous ovarian GnRH treatment. Arch Gynecol., 236:255-259

Hafez, E,S,E. 1952. Studies on the breeding season and reproduction of the ewe. 1. The breeding season in different environment. J. Agric. Sci., Camb. 42:189-199.

Hafez, E,S.E. and J.P. Scott 1962. The behaviour of domestic animals. Ist Edition, Baillicre Tindall.

Laws, S.C., J.M. Ferrell, T.E. Stoker and R.L. Cooper 2003. Pubertal development in female Wistar rats following exposure to propazine and atrazine biotransformation by-products, Diamino-S-chlorotriazine and hydroxyatrazine. Toxicological Sci., 76:190-200

Legan, S.J., H. I'Anson, B.P. Fitzgerald and MS.Jr. Akaydin 1985. Importance of short luteal phases in the endocrine mechanism controlling initiation of estrous cycles in anestrous ewes. Endocrinol., 117:1530-1536.

McLeod, B.J., B.R. Brinklow, J.D. Curlewis and A.S. Loudon 1991. Efficacy of intermittent or continuous of $\mathrm{GnRH}$ inducing ovulation in early and late seasonal anoestrus in the Pere David's deer hind (Elaphurus davidianus). J.Reprod. Fertil., 91:229-238.

McNatty, K.P., K.L. Isaacs, L. Gentle, L. Berry, N.L. Hudson, W. Young and B.J. McLeod 1998. Bioactive and immunoreactive FSH concentrations in ewe and ram lambs over the first year of life. Anim. Reprod. Sci., 51:155-166.

Papachristoforou, C., A. Koumas and C. Photious 2000. Seasonal effects on puberty and reproductive characteristics of female Chios sheep and Damascus goats born in autumn or in February. Small Rumin. Res., 38:9-15.

Pirl, K.G and T.E. Adams 1987. Induction of precocious puberty in ewe lambs by pulsatile administration of GnRH. J. Reprod. Fertil., 80:355-359. 
Quirke, J.F., G.H. Stabenfeldt and G.E. Bradford 1985. Onset of puberty and duration of the breeding season in Suffolk, Rambouillet, finnish Landrace, Dorset and Finn-Dorset ewe lambs. J. Anim. Sci. 60:1463-1471.

Racabarren, S.E., A. Lobos, E. Cendoyya, C. Correa and I. Rudolph 2000. Pituitary responsiveness to diurnal and nocturnal GnRH pulses in melatonin-treated ewe lambs. J. Reprod. Fertil. Dev., 12:45-50.

Rebuffe-Scribe, M., J. Eldh, L.O. Hafstrom and P. Bjorntorp, 1986. Metabolism of mammary, abdominal and femoral adipocytes in women before and after menopause. Metabolism, 35:792-797.

Suttie, J.M., D.L. Foster, B.A. Veenvliet, T.R. Manley and I.D. Corson 1991. Influence of food intake but independence of body weight on puberty in female sheep. J. Reprod. Fertile., 92:33-39.

Yamasaki, H., T. Douchi, S. yamamoto, Oki. Toshimchi, R. Kuwahata and Y. Nagata 2001. Body fat distribution and body composition during GnRH agonist therapy. Obstetrics \& Gynecology, 97:338-342. 


\title{
تسريع البلوغ الجنسى فى حمـلان إنـاث الرحمانى المولودة فى الخريف والشتاء بواسطة الحقن بالجونادوتروبين
}

\author{
أنس أحمد العربى سالم' ، سالم فهمى" ، أحمد مصطفى" \\ 'قسم الانتاج الحيوانى -كلية الزراعة-جامعة أسيوط

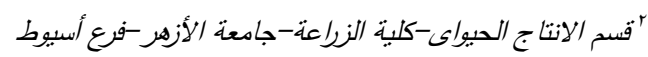

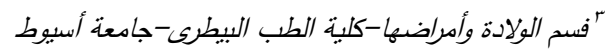

قحصت التجربة تأثثر وزن الجسم وموسم الولادة وحقن الجونادتروبين فى الوريد بمعدل (ه ميكروجرام/كجم وزن

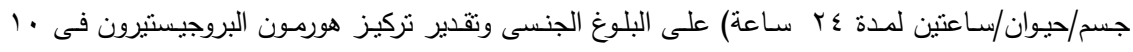

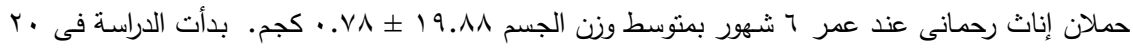

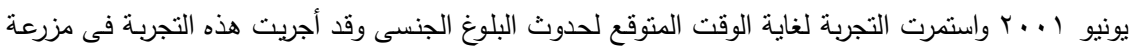

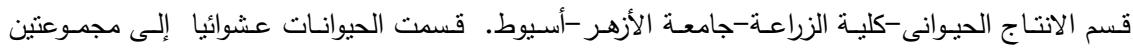

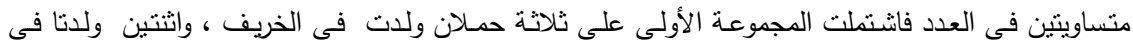

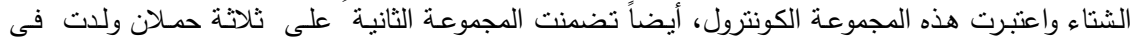

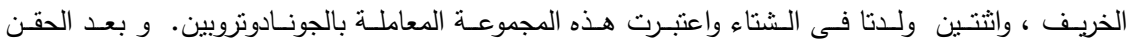

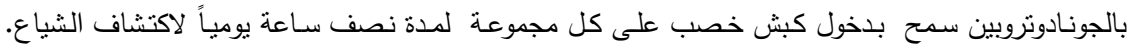

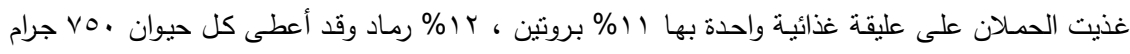

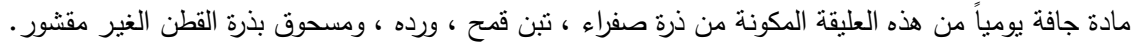

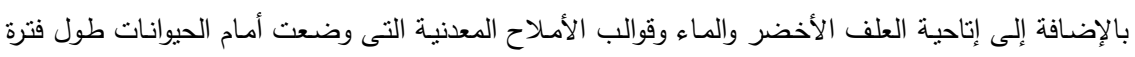

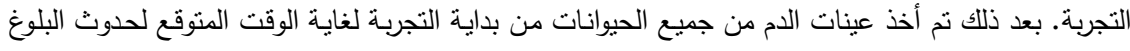

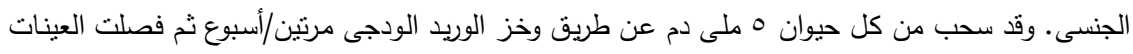
بواسطة الطرد المركزى للحصول على مصل الدم. ثم حفظت العينات بعد ذلك تحت - - ب درجة مئوية لحين

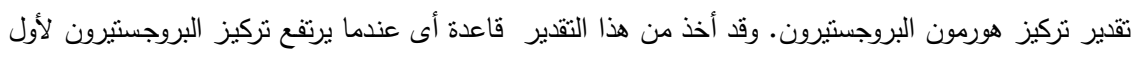

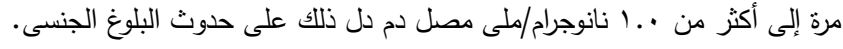

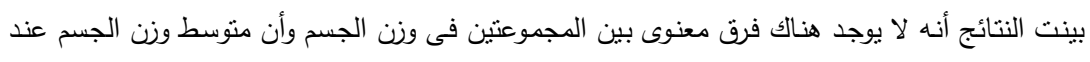

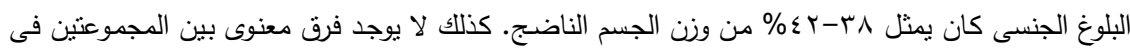

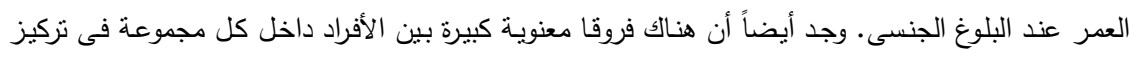

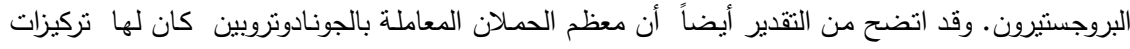

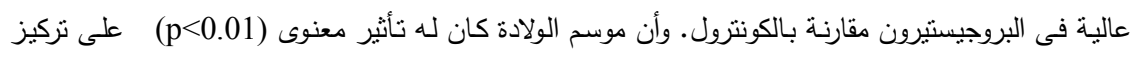

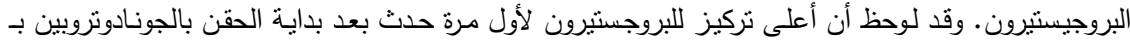

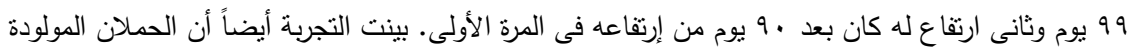


فى الثتاء حققت تركيوات عالية فى البروجيستيرون عند ارتفاعة لأول مرة بالمقارنة بحملان الكونترول المولودة

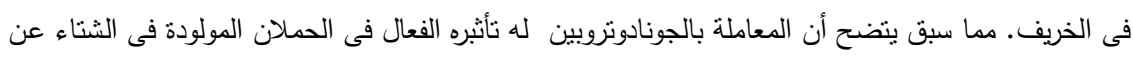

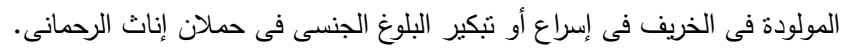

